\title{
CONTAMINATION OF CLARIAS GARIEPINUS FISH WITH PSYCHROTROPHS PARTICULARLY AEROMONAS SPECIES
}

\author{
BRR, A. A. $H^{a}$. and Sohair R. Basyoni ${ }^{b}$ \\ a; Provincial Tanta Laboratory - b; Provincial Marsa Matrooh Laboratorby \\ Animal Health Research Institute, Egypt.
}

\begin{abstract}
Fifty samples of fresh Clarias gariepinus fish were collected randomly from different markets at Tanta city, Gharbia governorate. These samples were examined for isolation and identification of psychrotrophic bact-eria, particulary Aeromonas species, the isolated strains of psychrotro-phic species were Acinetobacter 8\%,Aeromonas $56 \%$,Alcaligens 12\%,Chromobacterium 10\%, Psuedomonas $28 \%$ and Flavobacterium $6 \%$.

Further identification of Aeromonas species were recovered as Aermonas A.hydrophla, 30\% A.pumctata 16\% and A.salmonicida $10 \%$.

All Aeromonas speices were examined for their ability to produce lipolytic, proteolytic, hemolytic and Dnase activities in different percentages $78.6 \%, 71.4 \%, 82.1 \%$ and $67.9 \%$, respectively.

Concerning the antibiotic sensitivity of the isolated Aeromonas strains, theywere sensitive to enrofloxacin, gentamycin, oxytetracycline, tetracycline and nalidixic acid on other hand, they have a high resistance to amoxi-cillin, ampicillin, pencillin, erythromycin, and lincospectin. The public health significance of isolated strains and recommended sanitary measures were discussed.
\end{abstract}

Key Words: Psychrotrophs. Aeromonas . Clarias gariepinus. 


\section{INTRODUCTION}

Psychrotrophs are very important group of organisms causing food spoilage, they are found in water and soil and their growth range from $12{ }^{\circ} \mathrm{C}$ to $42{ }^{\circ} \mathrm{C}$. (Garbutt, 1997).

Aeromonas, Acinetobacter, Alcaligens, Chromobacterium,Flavobacterium and Pseudomonas species are commonly psychrotrophs isolated from seafood especially fresh fish(Banwart, 1989 and Jay, 1996). From the economic point of view, these organisms can cause some defects as off-odor, fruity, ammoniacal and $\mathrm{H}_{2} \mathrm{~S}$ odor (Banwart,1989), moreover, these organisms have a public health hazards to human where Acinetobacter species may occasional serious opportunistic infections including septicemia, pneumonia and meningitis, also Flavobacterium species have been recovered from wound, urinary tract and spinal fluid infections (Robinson, 2000).

Aeromonads are ubiquitous organisms in fresh water fish and shell fish (Isonhood and Drake, 2002). A eromonas species have been recognized as potential food borne pathogens for more than 20 year These organisms such as Aeromonas hydrophila can cause abdominal cramps and gastroenteritis.

Aeromonas species are important to the food industry due to their psychrotrophic nature and their ability to express a range of virulence factors under refrigerated storage conditions. Aeromonas species such as A.hydrophila can be regearded as both spoilage and potentially pathogens (Robinson2000).A.salmonicida is the causative agent of the fish disease called furuncullosis but human disease has not been described (Isonhood Drake, 2002). and Food of animal origin such as seafood have been considered an important vehicle for Aeromonas species infections (Altwegg et al., 1991., Kirov, 1993; Mattick and Donovan, 1998). 
A number of putative virulence factors such as autolysin, hemolysin, proteases, lipases and DNases that may play an important role in the development of disease cither in humans or in fish (Santos et al., 1999 and soler et al.,2002 ). All people are believed to be susceptible to Aeromonas gastroenteritis, although it is most frequently observed in very young children; individuals with impaired immune systems or underlying disease are susceptible to the more severe infections(Brema et al.,2003)In recent years Aeromonas group has received increasing attention as an agent of food borne diarrheal disease in human being (Palumbo et al., 1985).

The aim of this study was to determine the incidence of psychrotrophic bacteria in fresh water Clarias gariepinus with special reference to Aeromonas species and their ability to produce some virulence factors such as proteolytic, lipolytic, hemolytic and DNase activities, in addition to susceptibility of isolated Aeromonas to different types of antibiotics.

\section{MATERIALS AND METHODS}

\section{1- Collection of samples:}

A total of 50 samples of fresh water fish, Clarias gariepinus, were collected randomly from the local markets at Tanta city, Gharbia governorate.The collected samples were transported aseptically to the laboratory without undue delay for bacteriological investigations.

\section{2- Preparation of samples: -}

Each sample was based on its side over sterile plate holded by sterile forceps, the skin was sterilized by burning with ethyl alcohol 70\%, then removed. Ten grams of each fish muscle sample were aseptically transferred to $90 \mathrm{ml}$ of sterile trypticase soy broth containing $10 \mu \mathrm{g}$ ampicillin $/ \mathrm{ml}$ then incubated at $28^{\circ} \mathrm{C}$ for 24 hours. 0.1 milliliter from enriched broth was streaked into trypticase soy agar supplemented with ampicillin and incubated at $28^{\circ} \mathrm{C}-30^{\circ} \mathrm{C}$ for 48 hours $(\boldsymbol{F A O}, 1979)$.

\section{3-Isolation and Identification of psychrotrophic species:}

The suspected pale yellow colonies were picked upon nutrient agar slants and incubated at $28-30^{\circ}$ for 48 hours for further identification. The 
isolated strains were identified morphologically according to Cruickshank et al.(1975) and biochemically according to Macfaddin(1976), A.P.H.A (1992) and koneman, et al. (1994).

4- Detection of some virulence factors associated with isolated Aeromonas species:

a- Detection of lipolytic activity (Anguita et al., 1993).

It was determined by streaking of suspected Aeromonas species on tributyrin plate agar and incubated at $37^{\circ}$ for 24 hours The presence of a transparent zone around the colonies indicated lipase activity.

\section{b- Detection of proteolytic activity (Castro et al, 2003):}

Protolytic activity was tested on skim milk agar by streaking suspected Aeromonas species on to the plates and incubating at $37^{\circ} \mathrm{C}$ for 24 hours, the plates are flooded with $1 \%$ hydrochloric acid. The presence of clear transparent zone around the colonies indicated caseinase activity.

\section{c- Detection of DNase activity (Cruickshank et al., 1975):}

DNase agar plate was inoculated with a loopful of suspected colony by spotting and incubated at $37^{\circ} \mathrm{C}$ for 18 hours, then plate was flooded by normal hydrochloric acid(N HCL)which precipitates deoxyribonucleic acid (DNA) and turns plates cloudy. The appearance of clearing zone and absence of turbidity around colonies indicates DNase production.

\section{d- Hemolytic activity:}

Aeromonas species were plated onto sheep blood agar and incubated at $37^{\circ} \mathrm{C}$ overnight. The hemolytic activity was detected by presence of a clearing zone around colonies. (Quinn et al., 1994).

\section{5- Antibiotic susceptibility test:}

The isolated strains of Aeromonas species were suspended in trypticase soy broth for 18 hours, and then the suspension was adjusted to a turbidity equivalent to $0.5 \mathrm{McFarland}$ standard by adding sterile saline then it was suitable for sensitivity testing by disc diffusion method (Quinn 
et al.,1994). The discs contain the following antibiotics:amoxycillin, $10 \mu \mathrm{g}$; pefloxacin, $5 \mu \mathrm{g}$; Rifampicin, $5 \mu \mathrm{g}$; ampicillin, $10 \mu \mathrm{g}$; pencillin, $10 \mu \mathrm{g}$; tetra-

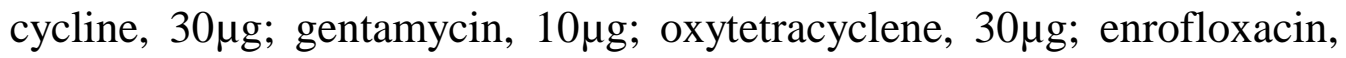
$10 \mu \mathrm{g}$; danofloxacin, $5 \mu \mathrm{g}$; norfloxacin, $10 \mu \mathrm{g}$; streptomycin, $10 \mu \mathrm{g}$ and nalidixic acid,30 $\mathrm{g}$ and neomycin, $10 \mu \mathrm{g}$ (Oxoid Limited,England).The entire surface of trypticase soy agar was streaked by a sterile cotton swab soaked in test strain suspension. After complete drying, antibiotic discs were placed on the surface of inoculated plates gently and after incubation overnight at $37^{\circ} \mathrm{C}$, the diameter of inhibition zone of Aeromonas species were measured and interpretated by referring to tables recommended by National committee for clinical laboratory standards (NCCLS ) (Finegold and Martin, 1982). Cultures were characterized as sensitive or resistant.

\section{RESULTS}

Table (1): Incidence of psychrotrophic species isolated from Clarias gariepinus fish samples $(\mathrm{n}=50)$.

\begin{tabular}{|l||c||c||}
\hline \multicolumn{1}{|c||}{ Psychrotrophic species } & NO & $\%$ \\
\hline \hline Acinetobacter species & & \\
A.caloaceticus & 4 & 8 \\
\hline Aeromonas species & 28 & 56 \\
A..hydrophila & 15 & 30 \\
A.punctata & 8 & 16 \\
A.salmonicida & 5 & 10 \\
\hline Alcaligens species & & \\
A.faecalis & 6 & 12 \\
\hline Chromobacterium species & 8 & 16 \\
C. lividum & 5 & 10 \\
C.violceum & 3 & 6 \\
\hline Pseudomonas species & 14 & 28 \\
Ps. vesicularies & 2 & 4 \\
Ps ..putrifaciens & 5 & 10 \\
Ps .diminuta & 3 & 6 \\
Ps..auriginosa & 4 & 8 \\
\hline Flovobacterium species & 3 & 6 \\
\hline
\end{tabular}

$\overline{\text { Kafr El-Sheikh Vet. Med. J. Vol. } 3 \text { No. } 1 \text { (2005) }}$ 
BRR, A. A. H \& Sohair, R. Basyoni.

Table (2): Incidence of some virulence factors of Aeromonas species isolated from Clarias gariepinus fish samples.

\begin{tabular}{|c|c|c|c|c|c|c|c|c|c|}
\hline \multirow{2}{*}{$\begin{array}{l}\text { Aeromonas } \\
\text { species }\end{array}$} & \multirow{2}{*}{$\begin{array}{l}\text { NO. of } \\
\text { species }\end{array}$} & \multicolumn{2}{|c|}{ Lipolytic } & \multicolumn{2}{|c|}{ Proteolytic } & \multicolumn{2}{|c|}{ Hemolytic. } & \multicolumn{2}{|c|}{ DNase } \\
\hline & & NO & $\%$ & NO & $\%$ & NO & $\%$ & NO & $\%$ \\
\hline A.hydrophila & 15 & 13 & 86.6 & 14 & 93.3 & 14 & 93.3 & 12 & 80 \\
\hline A.punctata & 8 & 5 & 62.5 & 4 & 50 & 6 & 75 & 3 & 37.5 \\
\hline A. salmonicida & 5 & 4 & 80 & 2 & 40 & 3 & 60 & 4 & 80 \\
\hline Total & 28 & 22 & 78.6 & 20 & 71.4 & 23 & 82.1 & 19 & 67.9 \\
\hline
\end{tabular}

Table (3): Suceptibility of Aeromonans species isolated from Clarias gariepinus for different types of antibiotics.

\begin{tabular}{|c|c|c|c|}
\hline Antibiotic disc & A. hydrophila & A. punctata & A.salmonicida \\
\hline Amoxycillin & $\mathrm{R}$ & $\mathrm{R}$ & $\mathrm{R}$ \\
\hline Ampicillin & $\mathrm{R}$ & $\mathrm{R}$ & $\mathrm{R}$ \\
\hline Danofloxacin & $\mathrm{V}$ & $\mathrm{S}$ & I \\
\hline Enrofloxacin & $\mathrm{S}$ & $S$ & $\mathrm{~S}$ \\
\hline Erythromycin. & $\mathrm{R}$ & $\mathrm{R}$ & $\mathrm{R}$ \\
\hline Gentamycin & $S$ & $S$ & $S$ \\
\hline Neomycin & $\mathrm{S}$ & I & $\mathrm{R}$ \\
\hline Pefloxacin & I & $\mathrm{V}$ & $\mathrm{R}$ \\
\hline Pencillin & $\mathrm{R}$ & $\mathrm{R}$ & $\mathrm{R}$ \\
\hline Rifampicin & $\mathrm{V}$ & $\mathrm{V}$ & $S$ \\
\hline Streptomycin & $\mathrm{S}$ & I & $\mathrm{V}$ \\
\hline Tetracyclene & $S$ & $S$ & $S$ \\
\hline Oxytetracyclene & $S$ & $S$ & $S$ \\
\hline Lincospectin & $\mathrm{R}$ & $\mathrm{R}$ & $\mathrm{R}$ \\
\hline Nalidixic acid & $S$ & $S$ & $S$ \\
\hline
\end{tabular}

S : sensitive I: intermediate.

R: resistant.

V: variable (some strains were sensitive and other were resistant)

$\overline{\text { Kafr El-Sheikh Vet. Med. J. Vol. } 3 \text { No. } 1 \text { (2005) }}$ 


\section{DISCUSSION}

Fresh water fish acts as a vehicle for many types of microorganisms. The chief source of fish contamination was water, soil and fish handlers (Youssef et al., 1985). Fish can acquire pathogenic microorganisms from the natural aquatic environments, from sewage contaminating harvesting areas as well as from contamination by workers, utensils, equipments during harvesting and transportation. (Frazier, 1967 and National Academy of Science, 1985).

A total of 63 psychrotrophic strains isolated from 50 samples of Clarias gariepinus fish collected from local markets at Tanta city, the most isolated species were Aeromonas $56 \%$ followed by pseudomonas $28 \%$ then Alacaligens 12\%, Chromobacterium 16\%, Acinetobacter 8\%., and Flav-obacterium 6\% as shown in table(1). Nearly similar results were obtained by Youssef et al. (1985); Banwart (1989); Gram and Huss (1996); Jay ( 1996); and El-Sheikh (2001), while a high incidence of psychrotrophic species, especially Flavobacterium $25 \%$ and Pseudomonas $36 \%$ isolated from Clarias lazera by Mousa and Mahmoud (1997).

Members of the genus Aeromonas are tyrpically aquatic bacteria which may be isolated from fresh water and estuarine fish(Janda, 1991). The results of our study recorded in table (1) indicated that Aeromonas species was the most strain ( 56\%) and the most prevalent isolates were A.hydrophila $30 \%$,A.punctata $16 \%$ and A.Salmonicida $10 \%$, these results agree with those reported by Jay (1996) and Brema (2003). A high incidence of Aeromonas hydrophila (36.1\%) in cat fish obtained by Wang and Silva ( 1999), while, Bastawrows and Mahmoud (1999) and ElSheikh( 2001). isolated A. hydrophila from fresh Clarias lazera fish in low incidence $18 \%$ and 6\%, respectively. Khalil (2004) isolated and identified 24 Aeromonas hydrophila strains from the muscles of Clarias lazera in 10\%, while El-Sheikh (2001) isolated A.punctata in high incidence $24 \%$. The high incidence of Aeromonas species in examined fish samples may be attributed to water contamination with human and animal Kafr El-Sheikh Vet. Med. J. Vol. 3 No. 1 (2005) 
effluents, during handling and distribution in local markets, where motile Aeromonas including A.hydrophila are common aquatic inhabitants and recognized as pathogens in fish (Shotts et, al.1972 and Rippey and Cabelli, 1979), also, A. hydrophila is one of the bacterial flora of surface water and considered as indicator of water pollution (Schubert, 1987). Another source of Aeromonas species may be asymptomatic human carriers particularly those working as food handlers (A.P.H.A, 1992). So, the harvesting of fish from polluted areas must be avoided, clean pans and utensils are used in handling of fish, strict hygienic measures during handling, transport and storage of fish.

Aeromonas species are considered as emerging food borne pathogens that associated with septicemia, gastroenteritis, endocarditis and wound infections in human being (Janda, 1991).

Pseudomonas species produce wound infection, burns, blue green pus, meningitis, urinary tract infections and may lead to rapid eye destruction (Aly, 1997). These bacteria may invade blood stream resulting in fatal sepsis. This occurs commonly in infants and debilitated persons (Brooks, et al., 1995).

A number of potential virulence factors which have a highly significant public health problem as well as economic importance,these factors include enterotoxins, cytotoxins, haemolysins, lipases and proteases production (Trust and Chipman, 1979).

Regarding the results recorded in table (2), 82.1\%, $78.6 \%$ and $71.6 \%$ of Aeromonas species have hemolytic, lipolytic and proteolytic activities whilemean, $67.9 \%$ of these species showing DNase activity.

Aeromonas hydrophila isolates were the most prevalent strains producing hemolytic activity at $93.3 \%$, proteolytic at $93.3 \%$, lipolytic at $86.7 \%$ and DNase at $80 \%$ activities than those obtained by A.punctata and A.salmonicida. These results are nearly agreed to great extent with those reported by Santos et al. (1988); Aly, (1997); Wang and Silva (1999) and Castro et al. (2003). Hemolytic and proteolytic activities act Kafr El-Sheikh Vet. Med. J. Vol. 3 No. 1 (2005) 
as a marker of pathology in fish (Rogulska et al., 1994 and Austin and Adams, 1996), also, Aeromonas organisms which had hemolytic and proteolytic in food of animal origin indicate that this food may play a significant role in the epidemiology of Aeromonas associated with gastroenteritis.(Aly, 1997).

The extensive use of antibiotics in veterinary practice and the addition of antibiotics as feed additives are considered to be the main cause of the high incidence of antibiotic- resistance organisms, especially among Gram-negative bacteria in domestic animals (Anderson, 1968).

The subtherapeutic use of antimicrobial drugs has played an important role in animal husbandry for control of disease efficiency of feed conversion. (Franco et al., 1990). Aeromonas species are zoonotic important. So, antimicrobial sensitivity test for isolated Aeromonas species are performed and found that $A$. hydrophila was sensitive to gentamycin, enrofloxacin, neomycin,nalidixic acid, streptomycin and oxytetracyclene, while A.punctata was sensitive to danofloxacin,enrofloxacin,gentamycin, oxy and tetracycline, moreover, A. salmonicida was sensitive to enrofloxacin, gentamycin, rifampicin and oxytetracyclene. On the other hand, amoxycillin, ampicillin, erythromycin, pencillin and lincospectin were resistant to isolated species of Aeromonads. Nearly our results agree to a great extent with those reported by Gado (1988);Radwan (1995);Bastawrows and Mahmoud(1999); Wang and Silva (1999); Megahed (2000); Badawy (2002) and Khalil (2004).

In conclusion our results indicated that psychrotrophic species were prevalent in Clarias gariepinus samples and all Aeromonas isolates have a high hemolytic, lipolytic, proteolytic and DNase activities, furthermore they are resistant to amoxycillin, ampicillin, pencillin, erythromycin and lincospectin antibiotics. The risk of illness associated with consumption of fish is reduced by good handling practices in home including thoroughly cooking of fish. Finally proper cleaning and sanitizing all utensils and contact surfaces. 


\section{REFERENCES}

- Altwegg, M.; Martinettil. G.; Luthy H.j. ; Rohrbach, M. (1991): Aerom-onas associated gastroenteritis after consumption of contaminated shrimp. Eur. J. Clin. Microbiol. Infect. Dis. 10, 44-45.

- Altweg,M. and Greiss,T,k.(1989): Aeromonas as human pathogen. Critical reviews in microbiology, 16(4Aly, S.M. (1997):Incidence andsignificance of Aeromonas hydrophila group in meat and some meat products in Assuit. Assuit Vet. Med. J. 38 (75): 28-38.

- Anderson, E.S.(1968): The ecology of transferable drug resistance in the Enterobacteria. Ann. Rev. Microbiol. 22131-180.

- Anguita,J.; Rodriguez -Aparicio, L.B.and Naharro, G. B(1999): Purific-ation, gene, amino acid sequence analysis and expression of an extracellular lipase from an Aeromonas hydrophila human isolates. Appl. Environ. Micr-obiol. 59, 2411-241.

- A.P.H.A. (1992): Compendium of methods for the microbiological examin-ation of foods. The American Public Health Association, Washington, D.C.

- Austin ,B. and Adams, C.(1996): Fish pathogens. In: Austin, B.; Altwegg, M.;Gosling,P.J.and Josef,S.(Eds).The genus Aeromonas. Wiley, Chichester, 198-243.

- Badawy, A. A. (2002): Studies on some types of bacteria and fungi isolated from fish. M.V.Sc.(Bacteriology, Immunology and Mycology).Fac. Vet. Med., Moshtohor, ZagazigUniversity.Benha Branch.

- Banwart, G.J.(1989): Basic Food Microbiology. Charman\&Hall. NewYork- Canada-Germany

- Bastawrows, A.F. and Mahmoud, A.A.(1999): Some Microbiological inv-estigations on Aeromonas hydrophila group in Oreochromis niloticus and Clarias lazera in Assuit Governorate. Assuit.Vet. Med. J. 40 (80):197-209.

- Brema, P.J; Fletcher, G.C. and Osborne, C.(2003): Aeromonas species in seafood. Crop and Food Research.NewZealand Institute for Crop and Food Research Limited. PP. 1-6. 
- Brooks, G.F., Butel, J.S.; Ornston, L.N; Jawetz,E; Melinick, J.I. and Adelberg, E.A.(1995): Medical Microbiology $20^{\text {th }}$ ed, PrenticeHall Intern-ational Inc. PP.218-221.

- Castro-Escarplli, G. Figueras, M.J.; Aguiera-Arreola, G.; Soler, L.; Fernandeez-Rendon, E.; Aparicio, G.O.; Guarro, J. and Chacon, M.R. (2003): Characterization of Aeromonas species isolated from frozen fishinte-nded for human consumption in Mexico. International Journal of Food Mic-robiology, 84, 41-49.

- Cruicksank, R.; Duguid, J.P.; Mamion, B.P. and Swain, R.H.A. (1975): $\quad$ MadicalMicrobiology, $12^{\text {th }}$ Ed. Vol 2, Churchill Livingstone Edinburgh, London and NewYork.

- El-Sheikh, N. I.A. (2001): Microbiological hazards of some marketed fish and their relation to the public health. Ph.D, Food Hygiene Department, Alexandria University.

- F.A.O.(1979): Manuals of food quality control(4-Microbiological analysis). Rome.

- Finegold, S.M. and Martin, W.T. (1982): Diagnostic Microbiology $6^{\text {th }}$ Ed. Th.C.V.Mosby Company, USA.

- Franco,D.A.;Webb,J.and Taylor, C.E. (1990): Antibiotic and sulfonamide residues in meat. Implicatios for human health. J. Food Protect. 53:178-185.

- Frazier, W.C. (1967): Food Microbiology, $2^{\text {nd }}$ ed. Mc-garaw HILL Book Company, New York and London.

- Fricker, C.R. and Tompsett, S. (1989): Aeromonas species in foods: A significant cause of food poisonining. International Journal of Food Microb-iology, 9: 17-22.

- Gado, M.S.M.(1988): Studies on some bacterial diseases of cultured fresh water fish in Kafr El-Sheikh Governorate. M.V.Sc. Thesis, Fac. Vet. Med. Cairo University.

- Garbutt, J . (1997): Essentials of Food Microbiology. Arnold. London-Sydney- Auckland. PP. 57-58.

- George, J. and Banwart, G. J. (1979): Basic Food Microbiology, AVT publishing company. INC.Westport Connecticut.

- Gracey, M.; Burke,V. and Robnos, J. (1982): Aeromonas associated gast-roenteritis. Lancet ii: 1304-1306. 
- Gram, L. and Huss, H.H. (1996): Microbiological spoilage of fish and fish products. International Journal of Food Microbiology, 33 (1): 121-137.

- Isnhood,J. H. and Drake, M. (2002): Aeromonas species in foods. Journal of Food Protect., 65, 575-582.

- Janda, J.M. ((1991): Recent advances in the study of the taxonomy, patho-genicity and infectious syndromes associated with the genus Aeromonas. Clinical Microbiol. Rev. 4: 397-410.

- Janda, J.M. and Abott, S.L., (1998): Evolving concepts regarding the genus Aeramons: an expanding panorama of species, disease presentations and Dis 27, 332-344.

- Jay, M.J.(1996): Modern Food Microbiology, $5^{\text {th }}$ ed. CHRMAN \& HALL. International Thomson Publishing. NewYork. Khalil,W.K.A.(2004): Prev-alence of bacterial causes of skin lesions among catfish from different local-ities. M.V. Sc Department of Microbiology Fac.Vet. Med. Suez Canal University.

- Ko, W.C.; Yu, K.W.; Liu, CH.Y.; Huang, CH.T.; Leu, H.S. and Chuang, Y.CH. (1996): Increasing antibiotic resistance in clinical isolates of Aeromonas strains in Taiwan. Antimicrobial Agent, Chemotherapeutic, 40, 1260-1262.

- KO,W.C.; Lee, H.C.;Chuang,Y, C.; Liu, C.C. W U, J.J. (2000): Clinical features and therapeutic implicationsof 104 episodes of microbial Aeramonas bacteraemia.J.Infect.40, 267-273.

- Kirov,S.M.(1993): The public health significance of Aeromonas species in foods. International Journal of Food Microbiology, 20:179-198

- Koneman, E.W.; Allen, S.D.; Janda, W.M.; Schreckenberger, P.C and Winn, J.R. (1994): Introduction to diagnostic microbiology. J.B. Lippincott Company. PP.117-123.

- MacFaddin, J.F. (1976): Biochemical tests for identification of medical bacteria, Waverley press. Inc. Baltimore. USA.

- Mahmoud, Y.EL-S.A. (1999): Quality monitoring of some farm fish mark-eted in Kafr EL-Sheikh Governorate. Assuit. Vet. Med. J. 41(82):152-161.

- Mattick, k.l. and Donovan, T.J. (1998): The risk to public health of Aeromonas in ready- to-eat sold products. Commun. Dis. Public Health.1, 263- 266. 
- Megahed,A.A. (2000): Studies on some Gram negative bacteria in fish. M. Sc. Thesis (Microbiology). Fac. Vet.Med. Seuz Canal Uniersity.

- Mousa, M.M. and Mahmoud, Y.E. (1997): Hygienic quality of newly caught fresh fish. Assuit. Vet. Med. J. 37(73): 219-233.

- National Academy of Science (NAS) (1985): Evaluation of the role of microbiological for foods and ingredients. National academy press, Washin-gton, D.C.

- Palumbo, S.A.; Maxino, F Willimams, A.G.; Buchanan, R.L. and Thayer, D.W. (1985): Strach-ampicllin agar for the quantitative detection of Aeromonas hydrophila. Appl. Environ. Microbiol. 50 (4):1027-1030.

- Quinn,P.J;Carter, M.E; Markry, B.K. and Carter, G.R. (1994): Clinical Veterinary Microbiology. Wolf Publishing. London. PP.237-243.

- Radwan, A. I .(1995): Bacteriological characterization of Gram negative bacteria isolated from fish. Ph.D.Thesis (Microbiology). Faculty of Vet.Med. Cairo University, Beni-Suef branch.

- Rippey, A.V.and Cabelli,V.J. (1979):Membrane filters procedure for enum-eration of Aeromonas hydrophila in fresh water. Appl. Environ. Microbiol, 38:108-113.

- Robinson, R.K.(2000): Encyclopedia in Food Microbiology. Academic Press. San Diego- San Francisco- New York BostonLondon.

- Rogulska, A.; Antychow, J.; and Zelazny, J. (1994): Hemolytic and prote-olytic activity of Aeromonas hydrophila and Aeromonas sobria as markers of pathogenicity for carp (Cyprinas carpiol). Medycyia Veterynaryina, 50 (5): 55-58.

- antos,Y.;Toranzo,A.E.; Barja, J.L.; Nieto,T.P. and Villa, T.G. (1988): Virulence properties and enterotoxin production of Aeromonas strains isola-ted from fish Journal of Infec. Immune, 56 (12): 3285 -3293.

- Santos, J.H.; Gonzalez. C. J.; Otero, A.; Guarro-Lopez, M.L. (1999): Hemolytic activity and siderophore production in different Aeromonas species isolated from fish .Appl. Environ. Microbiol. 65, $5612-5614$.

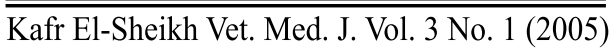


- Schubert,R.H.W.(1987): Ecology of Aeromonads and isolation from waters samples. Experientia, 43:351-354.

- Shotts, E.B.; Gains, J.L.; Martin, C.; Prestwood, A.K. (1972): Aeromonas induced deaths among fish and reptiles in a eutophic inland lake. J. Am. Vet. Med. Assoc. (161):603-603.

- Soler, L.; Figueras, M.J.; Chancon, M.R.; Vila, j.; Marco, F.; Murcia, A; Guarro, j. (2002): Potential virulence and antimicrobial susceptibility of Aeromanas recovered from fresh water and seawater .FEMS Immunol Med. Microbiol. (32):243-247.

- Trust, T.J. and Chipman,C.D. (1979): Clinical involvement of Aeromonas hydrophila Can. Med Assoc. J. (120): 942-947.

- Wadstronm, T .and Ljungh A. (1991): Aeromonas and Plesiomanas as a food and waterborne pathogen. International Journal of Food Microbiology

303-312.

- Wang, C. and Silva,J. (1999): Prevalence and characteristics of Aeromonas species isolated from processed channel catfish. J. Food Protection, 62 (1): 30-34.

- Youssef, H.; El-Timawy, A. M. and Hefnawy, Y. (1985): Microbiological quality of fresh water fish. Assuit Vet. Med. J. 4 (28): 109.

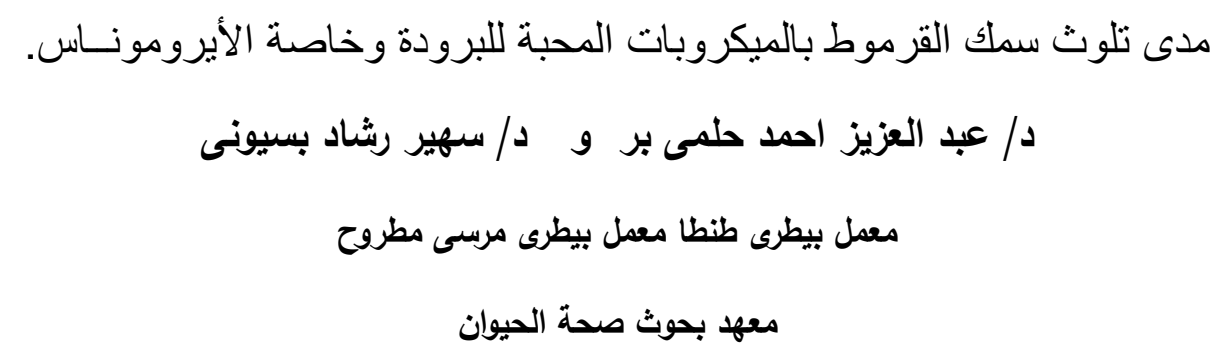

أجريت هذه الدر اسه على خمسين عينه من سمك القرموط نم جمعها من الأسواق بمدينة طنطا ، لاستيان مدى تلوثها بالميكروبات المحبة للبرودة وخاصة ميكروبات الأيروموناس ودراسة بعض الخواص الممرضة المتعلقة بها، وكذلك مدى حساسية ومقاومة هذه الميكروبات للمضادات الحيوية 
المختلفة ، وأوضحت الدر اسه على انه قد نم عزل وتصنيف الميكروبات المحبه للبروده بنسبة 8\%

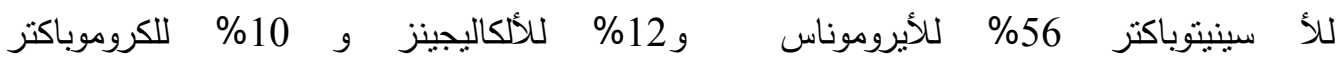
28\% ،للسودوموناس 66\% للفلافوباكتيريم كما تم عزل وتصنيف أنواع الآيروموناس بنسبة 30\% للايروموناس هيدروفيلا و16\% للايروموناس بنكتاتا و10\% لايروموناس سالمونيسيدا كما تضمنت النتائج على الأنشطه المحله للاهون و البروتين وتكسير كرات الدم الحمراء و حمض DNA لمعزولات الايروموناس و هى 78.6\% و 71.4\% و 82.1\% و67.9\% على الترتيب. باجراء اختبار الحساسية للمضادات الحيويه على معزولات الايروموناس اتضح إنها حساسة للجنتاميسين والانروفلوكساسين والاوكسيتتراسيكلين و حمض النالدكسيك وغير حساسة للبنسلين و الأمبسلين و الاموكسيسلين والارثرومايسين واللينكوسبكتين ونوقثت الاهميه الصحية والاقتصادية للميكروبات المعزولة و كذلك الاحتياطيات الواجب اتخاذها لحماية المستهلك. 